\title{
Peran Kepribadian Kesungguhan terhadap Krisis Usia Seperempat Abad pada Emerging Adulthood dengan Dukungan Sosial sebagai Mediator
}

\section{Conscientiousness and Quarter-Life Crisis in Emerging Adulthood: Social Support as a Mediator}

\author{
Dzikria Afifah Primala Wijaya ${ }^{1}$, Muhana Sofiati Utami ${ }^{2}$ \\ 1,2Fakultas Psikologi, Universitas Gadjah Mada \\ ${ }^{1}$ Fakultas Psikologi, Universitas Muhammadiyah Purwokerto
}

\begin{abstract}
The Quarter-Life Crisis is a developmental crisis that occurs in emerging adulthood. The Quarter-Life Crisis occurs due to the influence of several factors, including personality, sincerity and social support. The purpose of this study was to examine the role of conscientiousness in the Quarter-Life crisis in emerging adulthood with social support as a mediator. The participants of this study were individuals who were 286 people in the $18-25$ year age group. There are three measuring tools used, namely the Quarter-life Crisis Scale, Big-Five Inventory (BFI), and The Multidimensional Scale of Perceived Social Support (MSPSS). Mediation analysis using PROCESS, showed that social support mediates the role of conscientiousness in the Quarter-Life Crisis by $13 \%(-0.1286 ; \mathrm{p}<0.05)$. Thus, it can be concluded that social support functions as a mediator on the role of conscientiousness in the Quarter-Life Crisis.
\end{abstract}

Keywords: conscientiousness; emerging adulthood; social support; quarter-life crisis

Abstrak. Krisis usia seperempat abad merupakan krisis perkembangan yang terjadi pada masa emerging adulthood. Krisis usia seperempat abad terjadi karena pengaruh beberapa faktor, di antaranya kepribadian kesungguhan dan dukungan sosial. Tujuan dari penelitian ini adalah menguji peran kepribadian kesungguhan terhadap krisis usia seperempat abad pada emerging adulthood dengan dukungan sosial sebagai mediator. Partisipan penelitian ini adalah individu yang berada pada kelompok usia 18-25 tahun sebanyak 286 orang. Terdapat tiga alat ukur yang digunakan, yaitu Skala Quarter-life Crisis, Big-Five Inventory (BFI), dan The Multidimensional Scale of Perceived Social Support (MSPSS). Analisis mediasi menggunakan PROCESS, menunjukkan bahwa dukungan sosial memediasi peran kepribadian kesungguhan terhadap krisis usia seperempat abad sebesar $13 \%(-0,1286 ; p<0,05)$. Dengan demikian, dapat disimpulkan bahwa dukungan sosial berfungsi sebagai mediator atas peran kepribadian kesungguhan terhadap krisis usia seperempat abad.

Kata kunci: dukungan sosial; kepribadian; krisis; masa dewasa

Individu yang berada pada kelompok usia 18-25 tahun adalah individu yang sedang mengalami masa transisi dari remaja menuju dewasa yang disebut sebagai masa emerging adulthood (Arnett, 2000). Individu yang berada pada masa emerging adulthood ditugaskan 
untuk melakukan eksplorasi identitas pada tiga bidang utama, yaitu bidang percintaan, pekerjaan, dan pendidikan (Atwood \& Scholtz, 2008; Wood et al., 2018). Pada bidang percintaan, individu lebih menitikberatkan pada kualitas hubungan yang dapat dilihat dari rasa kasih sayang, keintiman, serta kepuasan, di mana hal-hal tersebut akan semakin meningkat ketika komitmen mulai terbentuk (De Goede et al., 2011; Wider et al., 2018) dan pernikahan menjadi salah satu bentuk komitmen pada bidang percintaan. Pada bidang pekerjaan, individu di masa emerging adulthood sering berganti-ganti pekerjaan karena memilih pekerjaan yang tidak hanya memberikan gaji layak, tetapi juga sesuai dengan identitas dan pemenuhan pribadi (Arnett, 2007). Sementara eksplorasi identitas pada bidang pendidikan di masa emerging adulthood terjadi sistem belajar yang lebih mandiri dan proses akademik tidak hanya ditujukan untuk belajar, namun juga untuk persiapan karier yang membuat sumber stres lebih tinggi dibandingkan dengan individu yang tidak melakukan eksplorasi bidang pendidikan (Launspach et al., 2016). Oleh karena itu, saat individu memilih bidang pendidikan selanjutnya yang mereka pilih tidak hanya sekedar mempertimbangkan favorit dan unggulan, tetapi juga disesuaikan dengan minat dan kebutuhan di masa depan.

Proses eksplorasi identitas yang dilakukan pada masa emerging adulthood tidak selalu berjalan lancar dan sesuai harapan, tetapi dapat menimbulkan gangguan dan hambatan yang menyebabkan gejala kecemasan dan depresi semakin memburuk (Reinherz et al., 2003). Di Indonesia, prevalensi depresi di tahun 2018 pada penduduk yang berusia lebih dari 15 tahun meningkat menjadi 9,8\%, setelah sebelumnya berjumlah 6\% pada tahun 2013 (Kementerian Kesehatan Republik Indonesia, 2018). Tentunya, hal tersebut termasuk bagi individu berusia 18-25 tahun yang sedang berada di masa emerging adulthood juga berpotensi mengalami depresi. Individu yang memiliki skor tinggi pada pengukuran depresi ketika berada di masa emerging adulthood, dilaporkan memiliki krisis perkembangan (Robinson et al., 2020). Artinya, individu yang mengalami depresi tinggi, juga mengalami krisis perkembangan pada masa emerging adulthood.

Krisis perkembangan yang terjadi pada masa emerging adulthood disebut sebagai krisis usia seperempat abad (quarter-life crisis). Krisis usia seperempat abad terjadi ketika individu berubah statusnya dari pelajar menjadi pekerja, kalaupun sudah bekerja, gaji yang didapatkan belum mampu memenuhi kebutuhan, menjalani kehidupan yang tadinya terstruktur menjadi lebih fleksibel, mulai menyewa atau membeli rumah untuk hidup mandiri (Chevalier \& Lindley, 2009; Robinson et al., 2020; Rugg et al., 2004). Lebih detailnya lagi, krisis ini terjadi ketika individu telah menyelesaikan masa sekolahnya, baik itu SMA maupun Perguruan Tinggi. Setelah menyelesaikan pendidikan, individu dihadapkan beberapa pilihan meliputi pendidikan, pekerjaan, dan percintaan yang berkaitan dengan masa depan. Beberapa pilihan yang dihadapi membuat individu merasa bingung dan takut terkait pilihan apa yang harusnya diambil. Kemudian, apabila pilihan tersebut sudah diambil, muncul pertanyaan berikutnya apakah pilihan yang diambil sudah benar atau belum. 
Terdapat faktor internal dan eksternal yang menjadi penyebab terjadinya krisis usia seperempat abad. Faktor internal merupakan hal-hal yang menyebabkan krisis usia seperempat abad yang berasal dari dalam diri individu, antara lain self-esteem (OlenikShemesh et al., 2018), coping (Mikula et al., 2018), religiusitas (Habibie et al., 2019), resiliensi (Balzarie \& Nawangsih, 2019), dan kepribadian (Baumert et al., 2017). Sementara faktor eksternal adalah hal-hal yang menjadi penyebab terjadinya krisis yang berasal dari luar diri individu, seperti masa transisi (Arnett, 2000), dukungan sosial (Praharso et al., 2017), kondisi karier (Haase et al., 2012), dan parenting (Kins et al., 2009).

Penelitian ini lebih memfokuskan pada faktor internal, yaitu kepribadian, khususnya kepribadian kesungguhan. Kurniasari (2017) menemukan bahwa kepribadian merupakan faktor predisposisi individu dalam menghadapi krisis. Artinya, kepribadian akan membuat individu cenderung memberikan respon atau reaksi yang berbeda ketika menghadapi krisis. Kepribadian merupakan pola karakteristik perilaku seseorang dalam pengertian yang luas, meliputi pikiran, perasaan, dan motivasi (Baumert et al., 2017). Individu dengan kepribadian kesungguhan (conscientiousness) akan memberikan reaksi yang berbeda dengan individu yang memiliki kepribadian pencemas (neuroticism). Individu dengan kepribadian pencemas berkorelasi negatif terhadap kemampuan menghadapi hal tidak menyenangkan bahkan merugikan karena kurang toleransi terhadap kekecewaan dan konflik bahkan mudah gugup ketika menghadapi masalah yang menurut kebanyakan orang sepele (Oshio et al., 2018; Ramdhani, 2012). Sementara kepribadian kesungguhan ketika menghadapi permasalahan cenderung memiliki kemampuan lebih baik dalam menghadapi hal-hal tidak menyenangkan bahkan merugikan karena memiliki perencanaan yang rapi, melakukan segala sesuatunya secara terencana, sabar, rajin, gigih, dan memiliki pendirian yang teguh (Ercan, 2017). Kepribadian kesungguhan juga ditemukan sangat berkaitan dengan ketekunan yang menjadi kekuatan individu dalam mengejar suatu tujuan dan menghadapi kesulitan maupun keputusasaan (Udayar et al., 2019). Kepribadian kesungguhan akan terus berusaha dan tidak menyerah bahkan ketika menghadapi kesulitan serta keputusasaan karena memiliki ketekunan yang membuatnya tidak akan berhenti sampai tujuannya tercapai.

Kepribadian kesungguhan menurut John dan Srivastava (1999) memiliki enam aspek, yaitu competence, order, dutifulness, achievement, self-discipline, dan deliberation. Aspek-aspek tersebut yang selama ini membantu individu dalam menghadapi tantangan dan permasalahan, termasuk membantu individu agar tidak memiliki krisis usia seperempat abad yang tinggi. Melalui aspek dutifulness, individu dengan kepribadian kesungguhan tidak akan pernah membiarkan orang lain untuk mengambil keputusan penting dalam hidupnya (Furnham, 2018), karena individu merasa kehidupannya adalah tanggung jawabnya dan mengetahui apa yang harus dieksplorasi ketika berada di masa emerging adulthood adalah salah satu bentuk tanggung jawab terhadap kehidupannya. Aspek dutifulness juga berkaitan dengan kepribadian kesungguhan yang memiliki 
kemungkinan kecil untuk mengingkari janji dan melewatkan janji (Jackson et al., 2010). Hal tersebut membantu individu dengan kepribadian kesungguhan dalam menstabilkan perkawinan (Solomon \& Jackson, 2014), sebagai salah satu bentuk tanggung jawab dan perjanjian besar yang terjadi dalam kehidupan seseorang.

Aspek lain yang juga membantu individu agar tidak memiliki krisis yang tinggi adalah aspek deliberation yang membuat individu dengan kepribadian kesungguhan memutuskan segala sesuatunya berdasarkan pengetahuan dan perencanaan yang detail dan jelas terkait tujuan apa yang ingin dicapai sebelum pada akhirnya memutuskan sesuatu (Pachur \& Spaar, 2015). Individu dengan kepribadian kesungguhan akan bertanya terlebih dahulu kepada orang di sekitarnya dan mencari informasi sebanyak mungkin sebelum memutuskan untuk melanjutkan pendidikan, melamar pekerjaan, atau bahkan memutuskan menikah yang membuat individu memiliki kecenderungan yang rendah untuk mengalami krisis. Menurut temuan Bayram dan Aydemir (2017), kepribadian kesungguhan berkorelasi positif terhadap gaya keputusan rasional, artinya individu dengan kepribadian kesungguhan akan memutuskan segala sesuatunya berdasarkan informasi yang komprehensif, membuat daftar pilihan, dan catatan evaluasi yang logis terkait daftar pilihan yang telah dibuat.

Aspek achievement juga dapat membantu individu agar tidak memiliki krisis yang tinggi karena individu dengan kepribadian kesungguhan digambarkan sebagai sosok pekerja keras, berambisi, percaya diri, banyak akal, dan gigih ketika dihadapkan dengan tantangan (Roberts et al., 2005, 2012). Individu dengan aspek achievement yang tinggi akan cenderung rajin dan mengerjakan sesuatu secara efisien, tidak menunda apalagi menghindari pekerjaan, serta cenderung tidak menyerah ketika menghadapi tantangan (Jackson \& Roberts, 2015). Hal-hal tersebut yang menjadikan kepribadian kesungguhan berkorelasi dengan keberhasilan pekerjaan dan prestasi akademik (Dudley et al., 2006; Noftle \& Robins, 2007).

Penelitian ini juga melakukan kajian terhadap salah satu faktor eksternal yang menyebabkan terjadinya krisis usia seperempat, yaitu dukungan sosial. Dukungan sosial dibutuhkan oleh individu untuk membantu menghadapi hal-hal tidak menyenangkan, termasuk krisis. Dukungan sosial yang mampu meningkatkan dinamika psikologis dan kontribusi secara afektif, fisik, dan kognitif yang diperoleh dari keluarga, teman, tetangga, dan institusi (Gulacti, 2010). Dukungan sosial dapat dibedakan menjadi dua jenis utama, yaitu received social support dan perceived social support (Vangelisti, 2009). Dukungan sosial yang berfokus pada kuantitas dan kualitas dari dukungan yang diberikan disebut received social support, sementara perceived social support adalah dukungan sosial yang mengacu pada ketersediaan dan kecukupan koneksi sosial yang dirasakan (Eagle et al., 2018). Pada penelitian ini, variabel dukungan sosial yang dikaji adalah perceived social support.

Dukungan sosial dibutuhkan oleh individu pada masa emerging adulthood, karena pada masa emerging adulthood terjadi perubahan yang sangat signifikan sehingga membutuhkan dukungan besar untuk membantu arah transisi dengan sukses (Wood et 
al., 2018). Individu yang berada di masa emerging adulthood mengalami perubahan yang sangat signifikan, seperti mulai mencari pekerjaan untuk memenuhi kebutuhan pribadi, mulai mencoba hidup mandiri dengan tidak bergantung pada orang tua, baik secara keuangan maupun tempat tinggal. Orang tua yang memberikan kemandirian dan dukungan secara seimbang dapat mendorong individu dalam hal eksplorasi dan pengembangan identitas (Luyckx et al., 2007). Sementara itu, bagaimana hubungan individu dengan orang tua akan membentuk keyakinan dan nilai yang diinternalisasi di masa depan (Schnyders \& Lane, 2018). Artinya, bagaimana individu berinteraksi dengan orang-orang dan lingkungan di sekitarnya dikorelasikan dengan kondisi hubungan individu dengan orang tuanya. Selain itu, dukungan emosional dari orang tua akan memberikan keamanan kepada individu ketika melangkah ke dunia luar dan mengembangkan hubungan baru (Collins \& Laursen, 2004). Rossi dan Mebert (2011) pun menemukan bahwa semakin maksimal dukungan sosial yang ada, maka semakin kecil individu tersebut mengalami depresi pada emerging adulthood. Begitu pula sebaliknya, semakin minimal dukungan sosial yang ada, maka semakin besar kemungkinan individu tersebut mengalami depresi.

Teman dan pasangan juga menjadi orang penting yang dibutuhkan dan keberadaannya dapat melengkapi serta menjadi sumber dukungan selama masa emerging adulthood (Markiewicz et al., 2006). Dukungan dari teman-teman juga berkaitan dengan kepuasan kerja (Rossi \& Mebert, 2011). Semakin besar dukungan sosial dari teman-teman, maka semakin tinggi tingkat kepuasan kerja yang dirasakan. Selain itu, menurut Schwartz (2016) teman online pada masa emerging adulthood bersifat melengkapi, sementara teman-teman offline, apalagi bertemu secara tatap muka menjadi penting untuk kesejahteraan selama berada pada masa emerging adulthood.

Dukungan sosial dapat meringankan tekanan psikologis, meningkatkan kesehatan emosional, dan mengatur emosi negatif (Donenberg, 2005; Li et al., 2020). Kemampuan dukungan sosial yang dapat meringankan tekanan psikologis, meningkatkan kesehatan emosional, serta mengatur emosi negatif tentunya dibutuhkan individu dalam menghadapi krisis usia seperempat abad sebagai episode yang terasa lebih sulit, stres, tidak stabil, memicu kecemasan, menyebabkan perasaan tidak berdaya dan panik (Robbins \& Wilner, 2001; Robinson et al., 2013). Dukungan sosial yang diberikan dapat berupa non-materi, seperti seseorang yang dapat diajak berbicara, dapat dimintai tolong untuk melakukan sesuatu, dapat memberikan penilaian positif dalam proses evaluasi (dukungan harga diri) atau dalam bentuk materi seperti barang maupun uang (Swickert et al., 2010). Pemaknaan positif pada dukungan sosial yang diterima terjadi karena individu menganggap hal tersebut sebagai bentuk dari mereka dicintai, dipedulikan, serta dihormati (Li et al., 2017). Perasaan-perasaan tersebut menumbuhkan emosi positif yang membantu individu menghadapi stres dan kecemasan (Folkman, 2008), sebagai suatu kondisi yang dialami ketika menghadapi krisis. 
Dukungan sosial juga dapat dipengaruhi oleh kepribadian kesungguhan. Semakin kuat kepribadian kesungguhan yang dimiliki oleh seseorang, maka semakin tinggi dukungan sosial yang dimiliki (Huang et al., 2019). Hal itu terjadi karena individu dengan kepribadian kesungguhan yang kuat memiliki emosi positif yang meliputi perasaan bahwa mereka dicintai, dipedulikan, dan dihormati (Li et al., 2017). Perasaan-perasaan itulah yang membuat individu memiliki persepsi baik bahwa hal-hal yang diterima adalah bentuk dukungan untuk dirinya dari lingkungan dan orang sekitar.

Penelitian sebelumnya menemukan bahwa dukungan sosial, khususnya perceived social support dapat berperan sebagai mediator atas peran kepribadian perfeksionisme terhadap depresi atau kecemasan (Dunkley et al., 2006). Dukungan sosial dapat mengurangi dampak peran kepribadian perfeksionisme terhadap depresi dan kecemasan. Depresi dan kecemasan merupakan suatu kondisi yang dialami ketika individu menghadapi krisis usia seperempat abad. Dengan demikian, adanya korelasi antara kepribadian perfeksionisme, depresi atau kecemasan, dan dukungan sosial, serta didukung oleh temuan-temuan sebelumnya, penelitian ini berasumsi bahwa dukungan sosial juga dapat menjadi mediator peran kepribadian kesungguhan terhadap krisis usia seperempat abad. Oleh karena itu, penelitian ini bertujuan untuk menguji peran kepribadian kesungguhan terhadap krisis usia seperempat abad pada emerging adulthood dengan dukungan sosial sebagai mediator.

Berdasarkan kajian teori dan penelitian sebelumnya, maka penelitian ini mengajukan hipotesis sebagai berikut: "Kepribadian kesungguhan berperan terhadap krisis usia seperempat abad dimediasi oleh dukungan sosial pada masa emerging adulthood".

\section{Metode}

Sebagai bentuk persetujuan dari Komite Etika Penelitian Fakultas Psikologi, penelitian ini sudah sesuai dengan kode etik penelitian psikologi yang dibuktikan oleh surat dengan nomor 5789/UN1/FPSi.1.3/SD/PT.01.04/2020. Penelitian ini melibatkan 286 orang yang berusia 18-25 tahun dengan jumlah partisipan perempuan ( $\mathrm{N}=231 ; 80,76 \%$ ) lebih banyak dibanding partisipan laki-laki ( $\mathrm{N}=55 ; 19,24 \%)$. Selanjutnya, berdasarkan usia, rata-rata usia partisipan yang terlibat pada penelitian ini adalah 18-24. Jumlah partisipan berdasarkan rentang usia hampir merata, yaitu berkisar $31-45$ orang (10,83\%-15,73\%), kecuali pada partisipan yang berusia 25 tahun hanya berjumlah 18 orang $(6,29 \%)$. 
Tabel 1.

Deskripsi Partisipan Penelitian

\begin{tabular}{lll}
\hline Kategori & Jumlah & Persentase (\%) \\
\hline Jenis Kelamin & & \\
- Laki-Laki & 55 & 19,24 \\
- Perempuan & 231 & 80,76 \\
Usia & & \\
- 18 & 44 & 15,38 \\
- 19 & 38 & 13,28 \\
- 20 & 32 & 11,18 \\
- 21 & 41 & 14,33 \\
- 22 & 31 & 10,83 \\
- 23 & 39 & 16,36 \\
- 24 & 45 & 15,73 \\
- 25 & 18 & 6,29 \\
\hline
\end{tabular}

Terdapat tiga variabel yang dikaji dalam penelitian ini, yaitu krisis usia seperempat abad sebagai variabel tergantung, kepribadian kesungguhan sebagai variabel bebas, dan dukungan sosial sebagai variabel mediator. Variabel krisis usia seperempat abad diukur menggunakan Skala Quarter-Life Crisis yang disusun oleh Agustin (2012) dan dilakukan uji coba alat ukur sebelum digunakan untuk mengambil data. Berdasarkan hasil uji coba alat ukur, reliabilitas yang dimiliki oleh Skala Quarter-Life Crisis adalah 0,92 dengan koefisien butir total bergerak dari 0,306 sampai 0,784. Namun, hasil uji alat ukur menggugurkan butir nomor 6 karena memiliki daya diskriminasi $<0,25$. Hal itu menyebabkan berkurangnya jumlah butir, dari 25 butir menjadi 24 butir. Selain itu, besaran reliabilitas yang dimiliki oleh Skala Quarter-Life Crisis berdasarkan data penelitian adalah 0, 94 dengan koefisien butir total 0,351 sampai 0,771.

Selanjutnya, variabel kepribadian kesungguhan diukur menggunakan Skala BigFive Inventory (BFI) dengan mengambil dimensi conscientiousnessnya saja yang terdiri dari 9 butir. Skala BFI yang digunakan pada penelitian ini dikembangkan oleh John (1990) dan diterjemahkan ke dalam bahasa Indonesia serta dilakukan standarisasi oleh Ramdhani (2012). Skala BFI juga menjalani uji coba alat ukur terlebih dahulu sebelum melakukan pengambilan data. Hasil uji coba alat ukur menghasilkan reliabilitas Skala BFI sebesar 0,81 dengan koefisien butir total bergerak dari 0,276 sampai 0,640. Selanjutnya, berdasarkan data penelitian, Skala BFI memiliki reliabilitas sebesar 0,75 dengan koefisien butir total 0,275 sampai 0,553.

The Multidimensional Scale of Perceived Social Support (MSPSS) yang digunakan pada penelitian ini disusun oleh Zimet et al. (1988) dan diterjemahkan oleh Winahyu et al. (2015) ke dalam bahasa Indonesia melalui proses back translation for cross-cultural research (Brislin, 1970). MSPSS juga diuji coba terlebih dahulu sebelum digunakan untuk 
pengambilan data. Berdasarkan hasil uji coba, diperoleh reliabilitas MSPSS sebesar 0,88 dan koefisien butir total bergerak antara 0,498 sampai 0,654. Selain itu, berdasarkan data penelitian, MSPSS memiliki reliabilitas sebesar 0,99 dengan koefisien butir total bergerak 0,450 sampai 0,718.

Ketiga skala yang digunakan dalam penelitian ini melalui daring menggunakan Google Form yang disebarluaskan melalui media sosial dan kelompok pesan singkat (group chat) dalam bentuk pengiriman narasi dan/poster. Pemilihan Google Form sebagai alat pengambilan data dikarenakan Google Form sudah sering digunakan dan bersifat familier. Selain itu, pengambilan data melalui daring karena dilakukan ketika masa pandemik Covid-19 yang mengharuskan untuk meminimalisir interaksi dengan orang banyak dan menjaga jarak.

Pengambilan data dilakukan dari tanggal 1 Desember sampai 5 Desember 2020. Penelitian ini melibatkan 286 partisipan yang berada pada rentang usia 18-25 tahun. Sebelum partisipan memberikan data yang dibutuhkan, lebih dulu diarahkan untuk mengisi informed consent terlebih dahulu. Informed consent dilampirkan di laman pertama dari google form yang disebarluaskan.

Sebelum melakukan uji hipotesis, data yang telah terkumpul dilakukan uji asumsi yang meliputi, uji normalitas, linearitas, multikolinearitas, dan heteroskedastisitas.. Selanjutnya dianalisis menggunakan PROCESS (Hayes, 2013) untuk mengetahui peran dukungan sosial sebagai mediator atas peran kepribadian kesungguhan terhadap krisis usia seperempat abad. Pengolahan data dilakukan menggunakan program penghitungan statistika SPSS versi 22.0.

\section{Hasil}

Penelitian ini melakukan kategorisasi data yang bertujuan untuk menempatkan individu ke dalam kelompok-kelompok berjenjang berdasarkan rumus kategorisasi data. Kategorisasi data yang dilakukan penelitian ini memiliki tiga jenjang yang terdiri dari, rendah, sedang, dan tinggi pada masing-masing variabel dengan skor hipotetik. Kategorisasi data dapat dilihat pada Tabel 2.

\section{Tabel 2.}

Kategorisasi Data

\begin{tabular}{lrrrrrr}
\hline \multirow{2}{*}{ Variabel } & \multicolumn{2}{c}{ Rendah } & \multicolumn{2}{c}{ Sedang } & \multicolumn{2}{c}{ Tinggi } \\
\cline { 2 - 7 } & \multicolumn{1}{c}{ Jml } & \multicolumn{1}{c}{ \% } & Jml & \multicolumn{1}{c}{$\%$} & \multicolumn{1}{c}{ Jml } & \% \\
\hline Krisis Usia Seperempat abad & 89 & 31,12 & 85 & 29,72 & 112 & 39,16 \\
Kepribadian Kesungguhan & 3 & 1,05 & 172 & 60,14 & 111 & 38,81 \\
Dukungan Sosial & 15 & 5,24 & 110 & 38,46 & 161 & 56,29 \\
\hline
\end{tabular}


Pada Tabel 2 dapat dilihat bahwa sebagian besar partisipan menunjukkan krisis usia seperempat abad dalam kategori tinggi $(\mathrm{N}=112,39,16 \%)$, kepribadian kesungguhan dalam kategori sedang ( $\mathrm{N}=172 ; 60,14 \%)$, dan dukungan sosial dalam kategori tinggi $(\mathrm{N}=161 ; 56,29 \%)$

Sebelum melakukan uji hipotesis penelitian, ada beberapa uji asumsi yang harus dilakukan, meliputi uji normalitas, uji linearitas, uji multikolinearitas, dan uji heteroskedastisitas. Berdasarkan uji normalitas menggunakan Kolmogorov-Smirnov pada Tabel 3 menunjukkan bahwa data variabel kepribadian kesungguhan terdistribusi secara normal $(p>0,05)$, sedangkan data variabel krisis usia seperempat abad dan dukungan sosial terdistribusi tidak normal $(p>0,05)$.

\section{Tabel 3.}

Hasil Uji Normalitas

\begin{tabular}{lll}
\hline Variabel & Signifikansi & Keterangan \\
\hline Krisis Usia Seperempat Abad & $p<0,05$ & Tidak normal \\
Kepribadian Kesungguhan & $p>0,05$ & Normal \\
Dukungan Sosial & $p<0,05$ & Tidak normal \\
\hline
\end{tabular}

Berdasarkan uji linearitas pada Tabel 4 menunjukkan bahwa seluruh data variabel kepribadian kesungguhan dengan variabel krisis usia seperempat abad memiliki hubungan yang linier $(\mathrm{F}=83,891$; deviation from linearity $p>0,05)$. Demikian pula variabel dukungan sosial dengan variabel krisis usia seperempat abad juga berhubungan secara linier ( $\mathrm{F}=20,615$; deviation from linearity $p>0,05)$.

\section{Tabel 4.}

Hasil Uji Linearitas

\begin{tabular}{llll}
\hline Variabel & $\boldsymbol{F}$ & $\begin{array}{l}\text { Deviation from } \\
\text { Linearity }\end{array}$ & Keterangan \\
\hline $\begin{array}{l}\text { Kepribadian Kesungguhan-Krisis Usia Seperempat } \\
\begin{array}{l}\text { Abad } \\
\text { Dukungan Sosial-Krisis Usia Seperempat Abad }\end{array}\end{array}$ & $\begin{array}{l}\text { 20,615 } \\
\text { Lut,05 }\end{array}$ & Linear \\
\hline
\end{tabular}

Selanjutnya melakukan uji multikolinearitas yang bertujuan untuk mengetahui apakah antar variabel independen memiliki korelasi. Hasilnya ditemukan bahwa variabel independen yang digunakan pada penelitian ini tidak terjadi multikolinearitas. Ditandai dengan hasil uji yang menunjukkan bahwa Variance Inflation Factors (VIF) di bawah 10 $(\mathrm{VIF}<10 ; \mathrm{KK}=1,067 ; \mathrm{DS}=1,067)$ dan Tolerance $>0,1$ (Tolerance $>0,1 ; \mathrm{KK}=0,937 ; \mathrm{DS}=0,937$ ) Terakhir, uji asumsi yang dilakukan adalah uji heteroskedastisitas yang bertujuan untuk mengetahui tidak adanya persamaan varian dari residual untuk semua pengamatan di dalam model regresi. Penelitian ini menggunakan Uji Glesjer untuk menguji 
heteroskedastisitas dan ditemukan bahwa signifikansi korelasi $p<0,05$. Artinya, tidak terjadi heteroskedastisitas pada data penelitian ini (lihat Tabel 5).

\section{Tabel 5.}

Hasil Uji Heteroskedastisitas

\begin{tabular}{lll} 
Variabel & Sig. & Keterangan \\
\hline Kepribadian Kesungguhan & 0,113 & Tidak terjadi \\
& & heteroskedastisitas \\
Dukungan Sosial & 0,432 & Tidak terjadi \\
& & heteroskedastisitas \\
\hline
\end{tabular}

Penelitian ini menggunakan PROCESS (Hayes, 2013) dengan tujuan untuk menguji peran kepribadian kesungguhan terhadap krisis usia seperempat abad, dengan dukungan sosial sebagai mediator. Penjelasan detailnya mengenai jalur peran tiap-tiap variabel dapat dilihat pada Gambar 1 dan Gambar 2.

\section{Gambar 1.}

Jalur Peran Kepribadian Kesungguhan terhadap Krisis Usia Seperempat Abad tanpa peran Mediasi

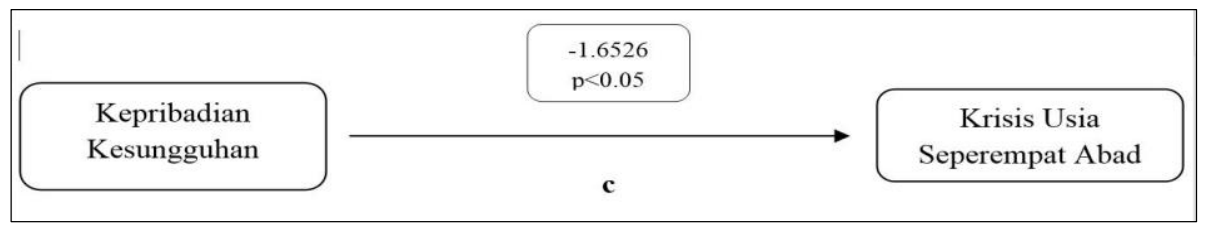

\section{Gambar 2.}

Jalur Peran Secara Keseluruhan

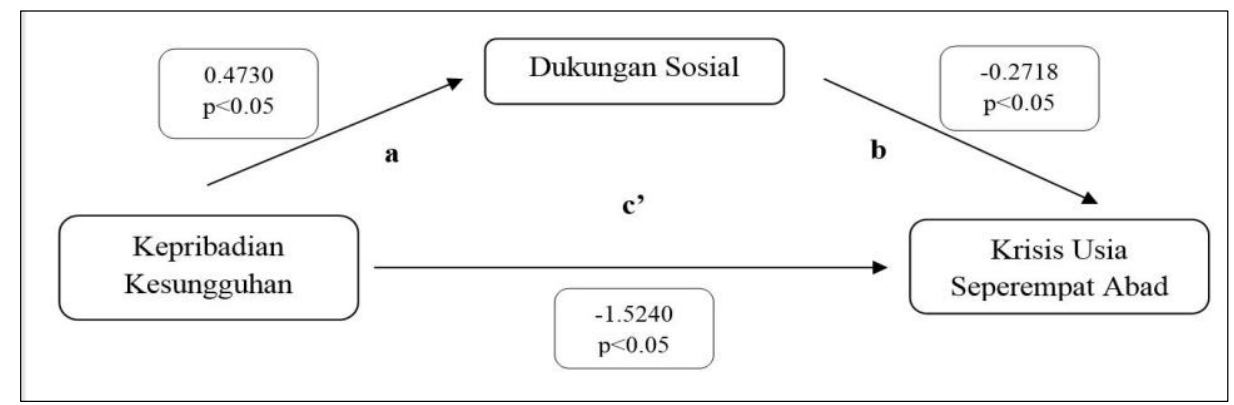


Berdasarkan data yang disajikan pada gambar 1, jalur c adalah jalur hubungan langsung variabel kepribadian kesungguhan terhadap krisis usia seperempat abad yang memiliki koefisien $-1,6526$ dengan signifikansi $p<0,05$. Artinya, semakin kuat kepribadian kesungguhan yang dimiliki oleh individu, maka semakin rendah krisis usia seperempat abad yang dialami. Selanjutnya, jalur a yang tertera pada Gambar 2, merupakan jalur hubungan variabel kepribadian kesungguhan terhadap dukungan sosial dengan koefisien 0,4730 dan memiliki signifikansi $p<0,05$. Artinya, semakin kuat kepribadian kesungguhan yang dimiliki oleh individu, maka semakin tinggi dukungan sosial yang dimiliki. Kemudian, jalur b yang tertera pada Gambar 2 adalah jalur hubungan dukungan sosial terhadap krisis usia seperempat abad yang memiliki koefisien -0,2718 dengan signifikansi $p<0,05$. artinya, semakin tinggi dukungan sosial yang dimiliki, maka semakin rendah krisis usia seperempat abad yang dialami. Berikutnya, jalur $c^{\prime}$ yang tertera pada Bagan 2 adalah hubungan variabel kepribadian kesungguhan terhadap krisis usia seperempat abad yang telah dimediasi oleh dukungan sosial, menunjukkan koefisien sebesar $-1,5240$ dengan signifikansi $p<0,05$. Dengan demikian, dapat disimpulkan bahwa dukungan sosial dapat berfungsi menjadi mediator atas peran kepribadian kesungguhan terhadap krisis usia seperempat abad.

Temuan selanjutnya adalah berkaitan dengan jalur indirect effect yang memperlihatkan besaran peran mediator. Pada jalur indirect effect besaran peran mediator dapat dilihat pada keterangan effect size. Diketahui effect size yang dimiliki oleh mediasi penelitian ini sebesar -0,1286 atau jika dikalikan 100\% menghasilkan besaran peran, yaitu $13 \%$. Artinya, dukungan sosial berfungsi secara signifikan sebagai mediator atas peran kepribadian kesungguhan terhadap krisis usia seperempat sebesar 13\%. Detailnya dapat dilihat pada Tabel 6 .

\section{Tabel 6.}

Detail Jalur Indirect Effect(s) Secara Keseluruhan

\begin{tabular}{llll}
\hline Effect & BootSE & BootLLCI & BootULCI \\
\hline$-0,1286$ & 0,0590 & $-0,2533$ & $-0,0292$ \\
\hline
\end{tabular}

\section{Tabel 7.}

Detail Sumbangan Aspek Dukungan Sosial terhadap Krisis Usia Seperempat Abad

\begin{tabular}{llll}
\hline Aspek & R & R Square & (\%) \\
\hline Dukungan Sosial dari Significant Other & 0,150 & 0,022 & 2,2 \\
Dukungan Sosial dari Keluarga & 0,277 & 0,076 & 7,6 \\
Dukungan Sosial dari teman & 0,183 & 0,033 & 3,3 \\
\hline
\end{tabular}




\section{Diskusi}

Terdapat tiga variabel yang dikaji oleh penelitian ini, yaitu krisis usia seperempat abad, kepribadian kesungguhan, dan dukungan sosial yang berfungsi sebagai mediator. Penelitian ini mengkaji ketiga variabel tersebut untuk melihat peran kepribadian kesungguhan terhadap krisis usia seperempat abad dengan dukungan sosial sebagai mediator. Semakin tinggi dukungan sosial yang dimiliki individu, maka akan mengoptimalkan peran kepribadian kesungguhan terhadap terjadinya krisis usia seperempat abad. Hasil uji analisis menunjukkan bahwa dukungan sosial berhasil menjadi mediator peran kepribadian kesungguhan terhadap krisis usia seperempat abad sebesar $13 \%$. Artinya, $87 \%$ berasal dari faktor krisis usia seperempat abad lainnya, seperti self-esteem, emotional intelligence, religiusitas, resiliensi, masa transisi, koping, kondisi karier, dan parenting (Balzarie \& Nawangsih, 2019; Brown et al., 2006; Habibie et al., 2019; Mikula et al., 2018; Permana et al., 2017; Walshe, 2018).

Temuan penelitian ini mendukung penelitian sebelumnya yang menemukan bahwa dukungan sosial berhasil menjadi mediator, namun pada peran kepribadian kesungguhan terhadap Post-Traumatic Stress Disorder (PTSD) (Huang et al., 2019). Selain itu, penelitian sebelumnya juga telah menunjukkan bahwa perceived social support dapat berperan sebagai mediator atas peran kepribadian perfeksionisme terhadap depresi atau kecemasan (Dunkley et al., 2006). Dukungan sosial dapat mengurangi dampak peran kepribadian perfeksionisme terhadap depresi dan kecemasan.

Pada pengukuran variabel dukungan sosial, terdapat tiga sumber dukungan sosial yang digunakan pada penelitian ini, yaitu teman, significant other, dan keluarga. Dari ketiga sumber dukungan sosial tersebut yang menyumbang paling besar adalah dukungan sosial dari keluarga (7,6\% dari 13\%). Artinya, dari ketiga sumber dukungan yang ada, dukungan keluarga lebih berperan dalam terjadinya krisis usia seperempat abad dibandingkan dengan sumber dukungan lainnya. Semakin tinggi ketersediaan dukungan sosial dari keluarga, maka semakin rendah krisis usia seperempat abad yang dialami oleh individu. Temuan tersebut mendukung penelitian sebelumnya yang menemukan bahwa dukungan sosial dari keluarga merupakan faktor pelindung depresi dan kecemasan yang lebih efektif ketika berada pada situasi stres (Grills-Taquechel et al., 2011; Roohafza et al., 2014). Dukungan sosial dari orang tua dapat berupa menghabiskan waktu bersama, memberi perhatian, pengetahuan, serta informasi yang berguna untuk memecahkan masalah, dan bantuan dalam bentuk instrumental yang praktis ketika diperlukan (Baranczuk, 2019). Dukungan sosial dari keluarga pada masa emerging adulthood juga dibutuhkan karena berkaitan dengan depresi yang dialami (Rossi \& Mebert, 2011). Semakin tinggi dukungan sosial yang dimiliki, maka semakin rendah depresi yang dialami individu ketika berada di masa emerging adulthood. Dukungan sosial dibutuhkan oleh individu pada masa emerging adulthood karena terjadi perubahan yang sangat signifikan sehingga membutuhkan dukungan besar untuk membantu arah transisi 
dengan sukses (Wood et al., 2018). Perubahan yang sangat signifikan tersebut seperti, perubahan status dari pelajar menjadi pekerja, menjalani kehidupan yang tadinya terstruktur menjadi lebih fleksibel, mulai menyewa atau membeli rumah untuk hidup mandiri, sementara pekerjaan yang dimiliki belum dapat memberikan penghasilan yang memenuhi kebutuhan (Chevalier \& Lindley, 2009; Robinson et al., 2020; Rugg et al., 2004).

Hasil lain yang ditemukan oleh penelitian ini adalah kepribadian kesungguhan memiliki korelasi negatif terhadap krisis usia seperempat abad secara keseluruhan maupun per-aspek. Semakin kuat kepribadian kesungguhan pada individu, maka semakin rendah krisis usia seperempat abad yang dialami. Kepribadian kesungguhan dianggap sebagai kepribadian yang dapat mengatasi peristiwa yang menegangkan dan secara signifikan berasosiasi dengan perubahan positif setelah mengalami kejadian traumatis (Campbell-Sills et al., 2006; Connor \& Davidson, 2003). Hal tersebut karena kepribadian kesungguhan ketika menghadapi krisis cenderung memiliki kemampuan lebih baik dalam menghadapi hal-hal tidak menyenangkan bahkan merugikan karena memiliki perencanaan yang rapi, melakukan segala sesuatunya secara terencana, sabar, rajin, gigih, dan memiliki pendirian yang teguh (Ercan, 2017). Selain itu, kepribadian kesungguhan ditemukan sangat berkaitan dengan ketekunan yang menjadi kekuatan ketika individu sedang mengejar suatu tujuan bahkan menemui kesulitan maupun keputusasaan (Udayar et al., 2019). Tentunya hal tersebut sangat berguna bagi individu ketika menghadapi permasalahan yang dirasa lebih sulit, stres, tidak stabil, dan menjadi titik balik penting dalam kehidupan seseorang (Robinson et al., 2013).

Hasil dari penelitian ini juga menunjukkan bahwa kepribadian kesungguhan berkorelasi positif terhadap dukungan sosial. Semakin kuat kepribadian kesungguhan yang dimiliki seseorang, maka semakin tinggi dukungan sosial yang dimiliki. Individu dengan skor kepribadian kesungguhan yang tinggi dan memiliki emosi positif yang menimbulkan perasaan dicintai, dipedulikan, dan dihormati (Li et al., 2017; Wood et al., 2008). Perasaan-perasaan itulah yang membuat individu memiliki persepsi baik bahwa hal-hal yang diterima adalah bentuk dukungan untuk dirinya dari lingkungan dan orang sekitar. Selain itu, kepribadian kesungguhan dapat menjadi salah satu hal yang dapat mempertahankan dukungan sosial karena cenderung mengingat dan menepati janji, rajin, mengikuti aturan kesopanan, bertanggung jawab, serta memiliki pengendalian diri yang baik (Hill et al., 2014; Jackson et al., 2010).

Secara keseluruhan peneliti menyadari bahwa penelitian ini masih memiliki kekurangan, yaitu partisipan yang masih didominasi oleh perempuan dan belum mewakili secara keseluruhan populasi individu 18-25 tahun. Oleh karena itu, generalisasi hasil penelitian hanya terbatas pada partisipan penelitian ini. Selain itu, penelitian ini hanya mengkaji variabel kepribadian kesungguhan dan dukungan sosial, sementara masih ada variabel lain yang menjadi faktor terjadinya krisis usia seperempat abad, seperti coping, religiusitas, harga diri, dan lain sebagainya. 


\section{Kesimpulan}

Penelitian ini menemukan bahwa kepribadian kesungguhan memiliki peran terhadap krisis usia seperempat abad pada masa emerging adulthood dimediasi oleh dukungan sosial. Dukungan sosial berfungsi menjadi mediator parsial atas peran kepribadian kesungguhan terhadap krisis usia seperempat abad. Semakin besar dukungan sosial yang dimiliki individu, maka akan mengoptimalkan peran kepribadian kesungguhan terhadap terjadinya krisis usia seperempat abad. Penelitian ini juga menemukan bahwa dukungan sosial yang bersumber dari keluarga memiliki sumbangan yang lebih besar dibanding dukungan dari teman maupun significant others.

\section{Saran}

Diharapkan pada penelitian selanjutnya dapat mengkaji variabel-variabel lain yang menjadi faktor berpengaruh terhadap terjadinya krisis usia seperempat abad, seperti pola asuh, coping, harga diri, resiliensi, religiositas, dan sebagainya. Sementara untuk psikolog, disarankan agar memberikan program yang dapat memperkuat kepribadian kesungguhan bagi individu pada masa emerging adulthood, agar tidak mengalami krisis usia seperempat abad. Selain itu, psikolog juga dapat memberikan psikoedukasi kepada masyarakat tentang pentingnya keluarga sebagai sumber dukungan sosial yang dapat membantu individu dalam menghadapi krisis usia seperempat abad.

Dengan demikian, harapannya individu yang berada pada masa emerging adulthood jangan ragu untuk meminta dukungan dari lingkungan sekitar, terutama keluarga. Dukungan yang diberikan dapat berupa waktu yang disediakan untuk mendengarkan keluh kesah atau cerita, memberikan pujian, saran, nasehat, bahkan dukungan materi. Dukungan sosial dibutuhkan karena dapat memaksimalkan kemampuan diri individu yang memiliki kepribadian kesungguhan dalam menghadapi krisis usia seperempat abad.

\section{Ucapan terima kasih}

Penelitian ini merupakan hasil akhir dari proses penyusunan tesis. Penulis ingin mengucapkan terima kasih kepada subjek penelitian yang telah membantu selama proses pengumpulan data. Tanpa subjek, penelitian ini tidak akan bisa berjalan dan berakhir dengan baik. Terima kasih kepada subjek penelitian yang sudah mau berpartisipasi dalam mengembangkan keilmuan Psikologi.

\section{Kontribusi penulis}

DAPW dan MSU merancang studi. DAPW mengumpulkan data kemudian menganalisis data bersama MSU. MSU membaca, mengedit, dan menyetujui versi final naskah. 


\section{Konflik kepentingan}

Para penulis menyatakan tidak ada konflik kepentingan dalam penelitian, penulisan, dan/atau publikasi artikel ini

Orcid ID

Muhana Sofiati Utami 0000-0001-9032-1606

\section{Kepustakaan}

Agustin, I. (2012). Terapi dengan pendekatan solution-focused pada individu yang mengalami quarterlife crisis. Universitas Indonesia.

Arnett, J. J. (2000). Emerging adulthood: A theory of development from the late teens through twenties. American Psychologist, 55(5), 469-480. https://doi.org/10.1037//0003-066X.55.5.469

Arnett, J. J. (2007). Emerging adulthood: What is it, and what is it good for? Journal Compilation, 1(2), 68-73.

Atwood, J. D., \& Scholtz, C. (2008). The quarter-life time period: An age of indulgence, crisis or both? Contemp Fam Ther, 30, 233-250. https://doi.org/10.1007/s10591-0089066-2

Balzarie, E. N., \& Nawangsih, E. (2019). Kajian resiliensi pada mahasiswa Bandung yang mengalami Quarter Life Crisis. Prosiding Psikologi, 5(2), 494-500.

Baranczuk, U. (2019). The five factor model of personality and social support: A meta analysis. Journal of Research in Personality, 81(2019), 38-46. https://doi.org/10.1016/j.jrp.2019.05.002

Baumert, A., Schmitt, M., Perugini, M., Johnson, W., Blum, G., Borkenau, P., Constantini, G., Denissen, J. J., Fleeson, W., Grafton, B., Jayawickreme, E., Kurzius, E., Macleod, C., Miller, L. C., Read, S. J., Roberts, B., Robinson, M. D., Wood, D., \& Wrzus, C. (2017). Integrating personality structure, personality process, and personality development. Journal of Personality, Eur. J. Pers, 31, 503-528. https://doi.org/10.1002/per.2115

Bayram, N., \& Aydemir, M. (2017). Decision making styles and personality traits. Proceedings of International Conference on Multiple Academic Disciplines, 1-11.

Brown, D. J., Cober, R. T., Kane, K., Levy, P. E., \& Shalhoop, J. (2006). Proactive personality and the successful job search: A field investigation with college graduates. Journal of Applied Psychology, 91, 717-726. https://doi.org/10.1037/00219010.91.3.717

Brislin, R. W. (1970). Back-translation for cross-cultural research. Jurnal of Cross-Cultural Psychology, 1(3), 185-216.

Campbell-Sills, L., Cohan, S. L., \& Stein, M. B. (2006). Relationship of resilience to personlity, coping, and psychiatric symptoms in young adults. Behav. Res. Ther, 44, 585-599.

Chevalier, A., \& Lindley, J. (2009). Overeducation and the skills of UK graduates. Journal of the Royal Statistical Society: Series A (Statistics in Society), 172(2), 307-337. https://doi.org/10.1111/j.1467-985X.2008.00578.x. 
Collins, W. A., \& Laursen, B. (2004). Changing relationships, changing youth: Interpersonal contexts of adolescent development. Journal of Early Adolescence, 24(1), 1-24.

Connor, K. M., \& Davidson, J. R. T. (2003). Development of a new resilience scale: The Connor-Davidson Resilience Scale (CD-RISC). Depression and Anxiety, 18, 76-82. http://dx.doi.org/10.1002/da.10113

De Goede, I. H. A., Branje, S., Van Duin, J., Van Der Valk, I. E., \& Meeus, W. (2011). Romantic relationship commitment and its linkages with commitment to parents and friends during adolescence. Social Development, 21(3), 425-442.

Donenberg, G. R. (2005). Youths and HIV/AIDS: Psychiatry's role in a changing epidemic. J. Am. Acad. Child. Adol. Psychiatry, 44, 728-747.

Dudley, N. M., Orvis, K. A., Lebiecki, J. E., \& Cortina, J. M. (2006). A meta analytic investigation of conscientiousness in the prediction of job performance: Examining the intercorrelations and the incremental validity of narrow traits. Journal of Applied Psychology, 91, 40-57.

Dunkley, D. M., Sanislow, C. A., Grilo, C. M., \& McGlashan, T. H. (2006). Perfectionism and depressive symptoms three years later: Negative social interactions, avoidant coping, and perceived social support as mediators. Comprehensive Psychiatry, 47, 106-115. https://doi.org/fvp4p5

Eagle, D. E., Hybels, C. F., \& Proeschold-Bell, R. J. (2018). Perceived social support, received social support, and depression among clergy. Journal of Social and Personal Relationships, 1-19. https://doi.org/10.1177/0265407518776134

Ercan, H. (2017). The relationship between resilience and big five personality traits in emerging adulthood. Eurasian Journal of Educational Research, 2017(70), 83-103. http://dx.doi.org/10.14689/ejer.2017.70.5

Folkman, S. (2008). The case for positive emotions in the stress process. Anxiety, Stress, and Coping: An International Journal, 21(1), 3-14. http://dx.doi.org/10.1080/10615800701740457

Furnham, A. (2018). A big five facer analysis of sub-clinical dependent personality disorder (dutifulness). Psychiatry Research, 270, 622-626. https://doi.org/10.1016/j.psychres.2018.10.052

Grills-Taquechel, A. E., Littleton, H. L., \& Axsom, D. (2011). Social support, world assumption, and exposure as predictors of anxiety and quality of life following a mass trauma. Journal of Anxiety Disorders, 25(4), 498-506. https://doi.org/10.1016/j.janxdis.2010.12.003

Gulacti, F. (2010). The effect of perceived social support on subjective well-being. Procedia Social and Behavioral Sciences, 2(2010), 3844-3849.

Haase, C. M., Heckhausen, J., \& Silbereisen, R. K. (2012). The interplay of occupational motivation and well-being during the transition from university to work. Developmental Psychology, 48, 1739-1751. https://doi.org/10.1037/a0026641

Habibie, A., Syakarofath, N. A., \& Anwar, Z. (2019). Peran religiusitas terhadap quarterlife crisis (QLC) pada mahasiswa. Gadjah Mada Journal of Psychology, 5(2), 129-138. https://doi.org/10.22146/gamajop.48948

Hayes, A. F. (2013). Introduction to mediation, moderation, and conditional process analysis. Guilford Press. 
Hill, P. L., Payne, B. R., Jackson, J. J., Stine-Morrow, E. A. L., \& Roberts, B. W. (2014). Perceived social support predicts increased conscientiousness during older adulthood. Journal of Gerontology, Series B: Psychological Sciences and Social Sciences, 69(4), 543-547. https://doi.org/10.1093/geronb/gbt024

Huang, J., Wang, X., Li, W., \& An, Y. (2019). The relationship between conscientiousness and posttraumatic stress disorder among young Chinese firefighters: The mediating effect of perceived social support. Psychiatry Research, 273(2019), 450455. https://doi.org/10.1016/j.psychres.2019.01.053

Jackson, J. J., \& Roberts, B. W. (2015). Conscientiousness. In T. A. Widiger (Ed.), The oxford handbook of the five factor model. Oxford University Press.

Jackson, J. J., Wood, D., Bogg, T., Walton, K. E., Harms, P. D., \& Roberts, B. W. (2010). What do conscientiousness people do? Development and validation of the behavioral indicators of conscientiousness. Journal of Research in Personality, 44, 501-511. https://doi.org/10.1016/j.jrp.2010.06.005

John, O. P. (1990). The "Big Five" factor taxonomy: Dimensions of personality in the natural language and questionnaires. In Handbook of Personality: Theory and Research (pp. 66-100). Guilford Press.

John, O. P., \& Srivastava, S. (1999). The big five trait taxonomy: History, measurement, and theoretical perspectives. In Handbook of personality: Theory and research (Vol. 2, pp. 102-138). Guilford Press.

Kementrian Kesehatan Republik Indonesia. (2018). Riset kesehatan dasar 2018. Kementrian Kesehatan Republik Indonesia.

Kins, E., Beyers, W., Soenens, B., \& Vansteenkiste, M. (2009). Patterns of home leaving and subjective well-being in emerging adulthood: The role of motivational processes and parental autonomy support. Developmental Psychology, 45, 1416-1429.

Kurniasari, A. (2017). Krisis paruh baya dan penanganannya. Sosio Informa, 3(2), 165-179.

Launspach, T., Van Der Deijl, M., Spiering, M., Heemskerk, M. M., Maas, E. N., \& Marckelbach, D. (2016). Choice overload and the quarterlife phase: Do higher educated quarterlifers experiences more stress? Journal of Psychological and Educational Research, 24(2), 7-16.

Li, J., Liang, W., Yuan, B., \& Zeng, G. (2020). Internalized stigmatization, social support, and individual mental health problems in the public health crisis. Int. J. Environ. Res. Public Health, 17(4507), 1-13. https://doi.org/10.3390/ijerph17124507

Li, M., Jiang, X., \& Ren, Y. (2017). Mediator effects of positive emotions on social support and depression among adolescents suffering from mobile phone addiction. Psychiatria Danubina, 29(2), 207-213.

Luyckx, K., Soenens, B., Vansteenkiste, M., \& Goossens, L. D. (2007). Parental psychological control and dimensions of identity formation in emerging adulthood. Journal of Family Psychology, 21, 546-550.

Markiewicz, D., Lawford, H., Doyle, A. B., \& Haggart, N. (2006). Developmental differences in adolescents and young adults' of mothers, fathers, best friends, and romantic partners to fulfill attachment needs. Journal of Youth and Adolescence, 35, 127-140.

Mikula, P., Nagyova, I., Vitkova, M., \& Szilasiova, J. (2018). Management of multiple sclerosis: The role of coping self-efficacy and self-esteem. Psychology, Health $\mathcal{E}$ Medicine, 23(8), 964-969. https://doi.org/10.1080/13548506.2018.1437277 
Noftle, E. E., \& Robins, R. W. (2007). Personality predictors of academic outcomes: Big five correlates of GPA and SAT scores. Journal of Personality and Social Psychology, 93(1), 116-130.

Olenik-Shemesh, D., Heiman, T., \& Keshet, N. S. (2018). The role of career aspiration, selfesteem, body esteem, and gender in predicting sense of well-being among emerging adults. The Journal of Genetic Psychology, 1-14. https://doi.org/10.1080/00221325.2018.1526163

Oshio, A., Taku, K., Hirano, M., \& Saeed, G. (2018). Resilience and big five personality traits: A meta-analysis. Personality and Individual Differences, 127, 54-60. https://doi.org/10.1016/j.paid.2018.01.048

Pachur, T., \& Spaar, M. (2015). Domain-spesific preferences for intuition and deliberation in decision making. Journal of Applied Research in Memory and Cognition, 4, 303-311. http://dx.doi.org/10.1016/j.jarmac.2015.07.006

Permana, R. H., Wardati, M. A., \& Sirodj, D. A. N. (2017). Gambaran krisis psikologis mahasiswa tingkat pertama program sarjana Universitas Islam Bandung. Journal of Psychological Research, 3(2), 92-103.

Praharso, N. F., Tear, M. J., \& Cruwys, T. (2017). Stressful life transitions and well-being: A comparison of the stress buffering hypothesis and the social identity model of identity change. Psychiatry Research, 247, 265-275. https://doi.org/10.1016/j.psychres.2016.11.039

Ramdhani, N. (2012). Adaptasi bahasa dan budaya inventori big five inventory. Jurnal Psikologi, 39(2), 189-207.

Reinherz, H. Z., Paradis, A. D., Giaconia, R. M., Stashwick, C. K., \& Fitzmaurice, G. (2003). Childhood and adolescent predictors of major depressive disorder in the transition to adulthood. American Journal of Psychiatry, 160, 2141-2147.

Robbins, A., \& Wilner, A. (2001). Quarter-life crisis. Bloomsbury.

Roberts, B. W., Chernyshenko, O. S., Stark, S., \& Goldberg, L. R. (2005). The structure of conscientiousness: An empirical investigation based on seven major personality questionnaires. Personnel Psychology, 58, 103-139. https://doi.org/doi:10.1111/j.17446570.2005.00301.x

Roberts, B. W., Lejuez, C., Krueger, R. F., Richards, J. M., \& Hill, P. L. (2012). What is conscientiousness and how can it be assessed? Developmental Psychology, 1-15. https://doi.org/10.1037/a0031109

Robinson, O. C., Cimporescu, M., \& Thompson, T. (2020). Wellbeing, developmental crisis, and residential status in the year after graduating from higher education: A 12-month longitudinal study. Journal of Adult Development. https://doi.org/10.1007/s10804-020-09361-1

Robinson, O. C., Wright, G. R. T., \& Smith, J. A. (2013). The holistic phase model of early adult crisis. Journal of Adult Development, 20, 27-37. https://doi.org/10.1007/s10804013-9153-y

Roohafza, H. R., Afshar, H., Keshteli, A. H., Mohammadi, N., Feizi, A., Taslimi, M., \& Adibi, P. (2014). What's the role of perceived social support and coping styles in depression and anxiety? Journal of Research in Medical Sciences: The Official Journal of Ishafan University of Medical Sciences, 19(10), 944-949.

Rossi, N. E., \& Mebert, C. J. (2011). Does a quarterlife crisis exist? The Journal of Genetic Psychology, 172(2), 141-161. https://doi.org/10.1080/00221325.2010.521784 
Rugg, J., Ford, J., \& Burrows, R. (2004). Housing advantage? The role of student renting in the constitution of housing biographies in the United Kingdom. Journal of Youth Studies, 7(1), 19-34. https://doi.org/10.1080/1367626042000209930

Schnyders, C. M., \& Lane, J. A. (2018). Gender, parent and peer relationships, and identification with emerging adulthood among college students. Journal of College Counseling, 21, 239-251. https://doi.org/10.1002/jocc.12106

Schwartz, S. J. (2016). Turning point for a turning point: Advancing emerging adulthood theory and research. Emerging Adulthood, 4(5), 307-317. https://doi.org/10.1177/2167696815624640

Solomon, B., \& Jackson, J. J. (2014). Why does personality predict divorce? Multiple pathways through satisfaction. Journal of Personality and Social Psychology, 106, 978 996.

Swickert, R. J., Hittner, J. B., \& Foster, A. (2010). Big five traits interact to predict perceived social support. Personality and Individual Differences, 48(2010), 736-741. https://doi.org/10.1016/j.paid.2010.01.018

Udayar, S., Urbanaviciute, I., \& Rossier, J. (2019). Perceived social support and big five personality traits in middle adulthood: A 4-year cross-lagged path analysis. Applied Research in Quality of Life. https://doi.org/10.1007/s11482-018-9694-0

Vangelisti, A. L. (2009). Challenges in conceptualizing social support. Journal of Social and Personal Relationships, 26, 39-51.

Walshe, O. (2018). The Quarter-Life Crisis: Investigating emotional intelligence, self-esteem, and maximization as predictors of coping self-efficacy. Dublin Business School.

Wider, W., Yuen, G. P., Ken, Y. L., \& Kuen, H. W. (2018). Perceived social support and romantic relationship quality: Better wingman, parent, or friend? Advances in Social Science, Education and Humanities Research, 229, 506-521.

Winahyu, K. M., Hemchayat, M., \& Charoensuk, S. (2015). Factors affecting quality of life among family caregivers of patients with schizophrenia in Indonesia. J Health Res., 29(Suppl.1), S77-82. https://doi.org/10.14456/jhr.2015.52

Wood, A. M., Maltby, J., Stewart, N., Linley, P. A., \& Joseph, S. (2008). A social-cognitive model of trait and state levels of gratitude. Emot 8., 121, 281-290.

Wood, D., Crapnell, T., Lau, L., Bennett, A., Lotstein, D., Ferris, M., \& Kuo, A. (2018). Emerging adulthood as a critical stage in the life course. In Handbook of life course health development (pp. 123-143). Departement of Pediatrics.

Zimet, G. D., Dahlem, N. W., Zimet, S. G., \& Farley, G. K. (1988). The multidimensional scale of perceived social support. Journal of Personality Assessment, 52(1), 30-41. 